\title{
Accounting Issues: An Essay Series Part V-Intangible Assets
}

Judy Laux, (Email: jlaux@coloradocollege.edu), Colorado College

\begin{abstract}
This article represents the fifth in a series of theoretical essays intended to supplement the introductory financial accounting course and investigates the accounting treatment and related conceptual connections for intangibles. In addition, intangibles present unique accounting issues, conceptual challenges, and measurement dilemmas not found with most other assets, warranting special coverage. The paper also presents scandalous accounting episodes that have made the headlines as well as both theoretical and empirical studies that might be of interest to both students and professors.
\end{abstract}

\section{INTRODUCTION}

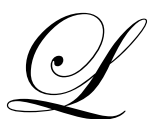

aux [2007(a)] proposes a theory-based introduction to the major accounting elements and employs a mountain-hiking analogy to discuss daily accounting dilemmas (the initial steps taken at the base of the mountain) and the adjusting process (in the foothills of the journey), with the ultimate goal of reflecting economic reality in the financial statements (at the peak of the mountain). "The Conceptual Framework at a Glance" section of the above-referenced work describes the hierarchy of accounting characteristics (displayed once more on the following page) as it relates to the mountain hiking experience. While you no doubt know a bit about the basic accounting associated with intangibles, the next section offers a brief overview. A section addressing the related conceptual connections and measurement issues follows this review, while the final portion of this article presents newsworthy examples of scandals as well as some good scholarly articles for further investigation.

\section{ACCOUNTING FOR INTANGIBLE ASSETS (IN BRIEF)}

Intangible assets lack physical existence (but do not include financial instruments, such as accounts receivable, or prepaid expenses). They include customer-related assets such as customer lists, artistic-related assets such as copyrights, contract-related assets such as franchises, technology-related assets such as patents, and finally, goodwill. Most introductory courses cover the basic historical cost-based accounting for intangibles. In short, intangible assets are recorded at cost, amortized (to expense) over the economic life (sometimes limited by legal life), and displayed on the balance sheet at unamortized cost. Intangible assets also are governed by asset impairment rules [covered in Part IV of this series, Laux 2007d]. Three exceptions to these general rules provide a number of accounting headaches and generate much professional disagreement: Goodwill, research and development, and computer software. The first is not recognized unless purchased (when one company buys another, paying more than the fair value of the combined tangible and identifiable intangible assets, less liabilities); the cost is also not amortized unless a limited life is expected. The second, research and development, is not recognized as an intangible asset at all but expensed as incurred. Software costs are initially expensed until "technological feasibility" is reached, at which time costs are capitalized (debited to an asset account) and amortized to future periods benefited. Thus, while accounting for intangibles generally might seem straightforward, the diverse nature of the assets in this category, along with the conceptual challenges presented in the following section, make this a topic worthy of special attention. 


\section{THE CONCEPTUAL FRAMEWORK AND INTANGIBLES}

Conceptually, as we look to the goal of decision usefulness at the mountaintop, we continually focus on both relevance and reliability. For intangibles, investors and creditors must find the reported value influential to their assessment of past economic events or helpful in predicting future cash flows - that is, they deem the reported asset value to be relevant information. In addition, the value must be reliably reported. With intangibles, the profession has "sided" with one of these qualitative characteristics (reliability) over the other (relevance). The following paragraphs elaborate on this ongoing tug-of-war.

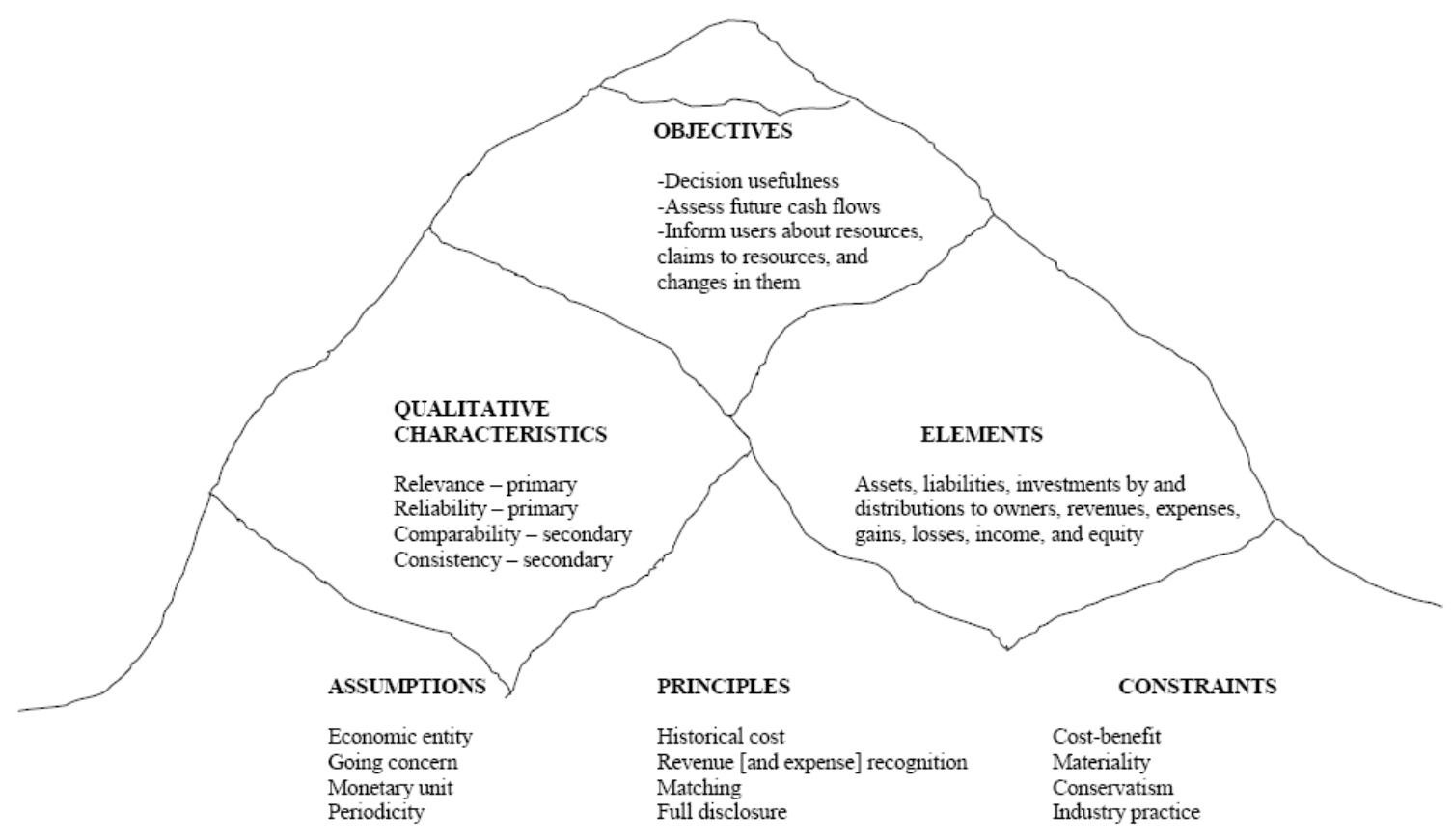

Intangible assets are generally not intended for sale but rather for use in keeping the company competitive into the future. Creditors rarely look to the value of these long-term assets in determining the ability to repay loans. For investors, it is not at all clear how the unamortized historical cost displayed on the balance sheet is weighed in projecting expected future cash flows, but the market place does place a value on intangibles. This becomes most apparent when one compares the market value of firms (number of shares outstanding times the market price per share) to their accounting book value (assets less liabilities). Lev [2001, p. 9, as cited in Austin, 2007, p. 65] found that the ratio of market price to book value of the US Standard and Poor 500 companies increased from just over 1:1 to about 6:1 from 1997 to 2001 . He concluded that, "for every six dollars of market value, only one dollar appears on the balance sheet, while the remaining five dollars represent intangible assets." Thus, the use of historical cost (and the book values based on this historical cost) limits the relevance of the value for intangible assets. The accounting profession has held that the reliability of a known (objective and verifiable) historical cost takes precedence over the potential relevance associated with reporting current market values for intangibles. The arguments are that, for many intangibles, the future benefits are not sufficiently quantifiable (estimable) for a value to be brought into the accounting system, and market values are absent. 
Accounting for intangibles at cost rather than market value reflects the accounting profession's emphasis not only on reliability but two additional qualities, conservatism and comparability, as well. The principle of conservatism holds that, if one is uncertain about the existence of future benefits, do not recognize the item as an asset. Furthermore, if a defensible range of values exists for the asset, report it at the lower end of that range. In the case of intangibles, because no ready market exists for most items, establishing a fair value is extremely difficult. If left to the judgment of accountants to value intangibles at their estimate of fair value, comparability from company to company would also be impaired, with some accountants reporting a higher value (perhaps at the behest of management...) than others for a comparable asset.

It was in the interests of comparability that the profession required that all research and development costs be expensed in the period incurred. Prior to this 1974 rule, some companies reported R\&D expenditures as an asset and amortized the cost of the asset over the perceived periods benefited, while others, less certain about the future benefits associated with research and development, simply expensed the costs as incurred. In the opinion of the accounting profession, this lack of comparability impeded decision usefulness, warranting a new accounting standard. Spiceland et al. [2007, p. 476] summarize it well: “[E]ven if R\&D costs do lead to future benefits, it's difficult to objectively determine the size of the benefits, and in which periods the costs should be expensed if they are capitalized." Thus, both reliability and the matching associated with periodicity played a major role in this accounting standard. The result, of course, is that many companies with valuable trademarks, patents, copyrights, and franchises are understating their assets (asset valuation), overstating their current expenses (expense recognition), and mismatching revenues and expenses. Many challenge also that, by over-accenting conservatism and reliability, we offer less timely information, because we are expensing these outlays in the current period without recognizing probable future benefits. If managers, in fact, can estimate those future benefits (or changes in them) today, statement readers would benefit, even if the managers' estimates lack perfect accuracy. (After all, it is better to be $30 \%$ wrong than $100 \%$ wrong!)

The intangible asset Goodwill requires special attention, because most students enter an introductory accounting course with a different definition than when they leave the course. We all think of goodwill as including such things as good customer relations, favorable location, popular products, competent management, and happy employees (with the resultant low turnover). True, these virtues can lead to the ability of a firm to make higher profits than comparable competitors lacking these things, but in accounting, goodwill rarely even appears on the balance sheet; yet we know many companies have goodwill (at least in the layperson's meaning of the word). As the introductory course instructs, however, goodwill is recognized formally (brought onto the accounting books) only when it is purchased (in an arms-length transaction) - that is, when one company buys another, paying more than "fair value" for the collective net assets. The fact that a company is willing to PAY for the assets makes it a reliable basis for bringing the asset onto the books. What seems contradictory, however, is that the process of valuing the goodwill requires a number of estimates (for the value of the other individual tangible and identifiable intangibles). That is, the accounting profession is willing to allow estimation of the value of these intangibles in inferring the value of the goodwill but is unwilling to permit estimating the value of intangibles already owned.

The rules for asset impairment apply to intangibles and require companies to write down the value of intangibles if evidence exists that their value is less than the unamortized cost currently appearing on the balance sheet. This results in adherence to both conservatism (reporting an asset at the lower end of a defensible range) and matching (since the loss is recognized during the period in which the event occurred.) Finally, companies must fully disclose their amortization choices; though straight-line amortization is the common choice, companies can also use other methods if deemed more appropriate for matching revenues and expenses. Once a method is adopted, it must be used with consistency from year to year. [For a good presentation of selecting the appropriate amortization period for intangibles, see Mueller, 2004.] Though intangibles-related scandals are not rampant, the next section offers some of the times when companies have elected to stray from the path to the mountaintop, resulting in scandals that made the news. The section also looks at the vast body of literature-theoretical and empirical — related to the accounting treatment of intangible assets. 


\section{INTANGIBLE ASSETS IN THE NEWS AND LITERATURE}

How might companies use intangibles accounting inappropriately, and what news stories have emerged from this abuse? While scandalous accounting related to intangibles rarely makes the headlines, three areas of potential abuse require some scrutiny: Intangibles valuation related to business combinations, "big bath" accounting, and its close cousin, income smoothing.

When one company buys another, often at a premium above the fair value of the net assets, it must bring the collection of assets onto its books at fair value, separating buildings, equipment, and land from such things as trademarks and other identifiable intangibles. This process offers the opportunity to "fudge" the numbers somewhat, placing more (or fewer) dollars in asset accounts that will (or will not) be written off over a longer (or shorter) estimated useful life. For example, when Hewlett-Packard acquired Compaq Computer Corporation in 2002, \$1.4 billion of the $\$ 24$ billion purchase price was assigned to the Compaq tradename, an intangible asset that was not to be amortized because it was determined to have an indefinite life. The more dollars placed in intangible accounts such as tradenames and goodwill, the more assets appear on the balance sheet and the fewer expense dollars appear on future income statements. Thus, valuation of intangibles at the merger stage carries a vast amount of weight in future financial statement presentations.

Inappropriate valuation at the point of acquisition often has resulted in what many perceive as "big bath" accounting in subsequent periods. When already faced with a bad year (earnings falling short of expectations), companies often decide to take revaluation losses, including write-downs of such things as goodwill (impairment), in-process research and development (a subset of R\&D for which capitalization and subsequent amortization are required), and other intangibles to "take the hit" in a single year, reducing future amortization expense and buoying up future earnings. As Spiceland [2007, p. 482] reports: "A profusion of large-percentage write-offs caused the SEC to scrutinize the amounts allocated to in-process R\&D and, in some cases, require the write-offs to be reduced. For example, the $\$ 37$ billion acquisition of MCI by WorldCom originally included a $\$ 7$ billion amount allocated to in-process R\&D. The SEC convinced WorldCom to reduce this amount to $\$ 3.1$ billion."

Income smoothing (or manipulating income to reflect less variation in income than economic reality might suggest) represents a third area with a potential for accounting abuse. Examples of such abuse that have made the headlines include Waste Management (which inflated profits by manipulating amortization and depreciation rates), Pinnacle Micro (which amortized engineering costs to avoid a loss, essentially treating these expenses as an intangible asset), and Sunbeam (which capitalized and amortized product development costs that by GAAP should have been expensed). In addition, in 1996, Sunbeam reduced property, plant, and equipment and trademarks by $\$ 92$ million, lowering its depreciation and amortization expenses in 1997. As a matter of fact, Sunbeam has used such a number of questionable accounting techniques that the company forms the basis for an excellent case study by Stanwick et al., "Sunbeam Corporation: 'Chainsaw Al' and the Quest for a Turnaround." [For other coverage of such antics, see "Dangerous Games," 1997, and "Earnings Hocus-Pocus...," 1998.] These few stories of accounting gone bad represent a miniscule portion of the body of literature devoted to intangibles, as many scholars have wrestled with accounting for intangibles, both conceptually and empirically. A representative sample of this scholarly literature follows.

For a good summary of the conceptual articles prior to 2003, see the American Accounting Association Financial Accounting Standards Committee's 2003 work (pp. 176-79). The current study looks only at the "seminal" article (Lev and Zarowin, 1999) and approachable articles from 2003 to the present. Because intangible assets represent one area where relevance takes a back seat to reliability, it should not be surprising that theoretical arguments abound. In "The Boundaries of Financial Reporting and How to Extend Them," Lev and Zarowin argue that the lack of relevance of reported intangibles values not only results in a deterioration in the usefulness of this information but also a mismatching of revenues and expenses, especially with such items as restructuring costs and R\&D expenditures, which "... are immediately expensed, while the benefits are recorded later and are not matched with the previously expensed investments" (pp. 353-54). The authors propose capitalization of intangible investments and a systematic restatement of financial reports when additional information becomes available. 
An opposing opinion comes from Kanodia et al. [2003] who argue that "measuring intangibles is not unambiguously desirable," because measurement often leads to estimated cash flows that are unreliable. They suggest that "intangibles should be measured only when their relative importance in constituting the firm's capital stock is high and when they can be measured with sufficiently high precision" (p. 116). Kumar [2005, p. 72] encourages "both economists and accounting professionals to conduct empirical research necessary to develop better objective methods for valuing intangible assets so that such valuations could form part of standard financial disclosures." Barth [2006, p. 271] takes it one step further, stating that "today's financial statements should include estimates of the future," as it is these up-to-date expectations of the future that are most useful in making economic decisions. Using the hierarchy of accounting characteristics (p. 275), the author makes a strong case for fair value accounting that goes far beyond today's GAAP and more nearly replicates current international accounting standards. In "The Value Relevance of Intangibles: The Case of Software Capitalization," Aboody and Lev [1998, p. 162] point out: "... software capitalization can be easily undone by subtracting the periodic capitalization figure from reported earnings and the capitalized software asset from total assets and equity. At best, capitalization is informative about the success of software development programs and at worst the information can be ignored." Finally, Wyatt [2005, p. 967] contends that forcing managers to account for such intangibles as goodwill and R\&D in a specified way (not permitting amortization of the former and expensing the latter), "tends to reduce, rather than improve, the quality of the balance sheet and investors' information set." Managers are in the best position to gauge whether an item possesses future benefits, and while there might be a range in the accuracy of estimates and levels of honesty, the overall usefulness of information would be enhanced. Just how "useful" reported financial information is provides the focus of the bulk of the empirical literature related to intangibles, covered in the following paragraph.

Most empirical studies testing the usefulness of accounting information attempt to determine whether reported earnings more closely parallel market prices after an accounting change. While an entire body of methodological literature is devoted to arguing about the quantitative aspects of this approach, our focus is on the articles designed to test the usefulness of accounting for intangibles. The most noteworthy accounting changes have included the required expensing of research and development (1974), capitalization of software development costs (1985), and goodwill amortization (discontinued in 2001). Here are some sample findings:

- $\quad[$ [T]here is a statistically significant decline in earnings usefulness for firms forced to switch from capitalizing to expensing R\&D outlays..." [Loudder and Behn, 1995, p. 185]

- $\quad$ "R\&D or other intangibles are market-value relevant in...high-tech firms." [Liu, 2006, p. 293] But, "because R\&D ventures in high-tech industries are multistage projects with many sources of risk, it is hard for investors or even managers to precisely evaluate the economic value of innovations from different stages." [Liu, 2006, p. 320]

- $\quad$ "We find a positive association between analysts' forecast error and the firm's intangible intensity that deviates from the industry norm. We also find that analysts' forecast errors are greater for firms with diverse and innovative technologies." [Gu and Wang, 2005, p. 1673]

- $\quad$ "...analyst coverage is significantly greater for firms with larger research and development and advertising expenses relative to their industry, and for firms in industries with larger research and development expense. ...analysts expend greater effort to follow firms with more intangible assets..." [Barth et al., 2001, p. 1]

- $\quad$ "We do not believe...that evidence of a decline in the value relevance of financial information can be attributed solely, or even primarily, to the increasing number and importance of high-technology firms in the economy." "...high-technology firms have not experienced a greater decline in relevance than lowtechnology firms." [Francis and Schipper, 1999, p. 347; p. 350]

- $\quad$ "We show that the persistence of bank abnormal earnings...var[ies] with the level of unrecorded intangible assets." [Kohlbeck and Warfield, 2007, p. 23]

This sampling of the empirical literature indicates that many scholars might support a move from reliability towards relevance in an attempt to help the market (and market analysts) better gauge firm valuation and potential for generating future cash flows. But the debate will continue for years to come! 


\section{THIS SERIES CONTINUES}

This article offered the fifth installment in this continuing series of brief articles devoted to connecting the theoretical constructs of the conceptual framework with the major accounting elements. It covered some of the conceptual ideas related to intangibles, featured a few headline stories, and reviewed some approachable articles addressing issues related to intangibles. The next installment in the series will look at the last of the asset category items, investments in marketable securities.

\section{REFERENCES}

1. Aboody, David and Baruch Lev. 1998. The Value Relevance of Intangibles: The Case of SoftwaremCapitalization. Journal of Accounting Research. Vol. 36 Supplement: 161-191.

2. AAA Financial Accounting Standards Committee. 2003. Implications of Accounting Research for The FASB's Initiatives on Disclosure of Information about Intangible Assets. Accounting Horizons. Vol. 17, No.2: $175-185$.

3. Austin, Lloyd. 2007. Accounting for Intangible Assets. University of Auckland Business Review. Autumn: 63-72.

4. Barth, Mary E. 2006. Including Estimates of the Future in Today's Financial Statements. Accounting Horizons. Vol. 20, No. 3: 271-285.

5. Barth, Mary E.; Ron Kasznik, and Maureen F. McNichols. 2001. Analyst Coverage and Intangible Assets. Journal of Accounting Research. Vol. 39, No. 1: 1-34.

6. Earnings Hocus-Pocus: How Companies Come Up with the Numbers They Want. 1998. Business Week. October 5, p. 135.

7. Financial Accounting Standards Board. 1974. Accounting For Research and Development Costs. Statement of Financial Accounting Standards, No. 2. Stamford, Conn.

8. 1980. Qualitative Characteristics of Accounting Information." Statement of Financial Accounting Concepts No. 2. Stamford, Conn.

9. 1985. Accounting for the Costs of Computer Software to be Sold, Leased, or Otherwise Marketed. Statement of Financial Accounting Standards No. 86. Stamford, Conn.

10. 2001. Goodwill and Other Intangible Assets. Statement of Financial Accounting Standards No. 142. Norwalk, Conn.

11. Francis, Jennifer and Katherine Schipper. 1999. Have Financial Statements Lost Their Relevance? Journal of Accounting Research. Vol. 37, No. 2: 319-352.

12. Gu, Feng and Weimin Wang. 2005. Intangible Assets, Information Complexity, and Analysts' Earnings Forecasts. Journal of Business Finance \& Accounting. 32(9) \& (10), November/December: 1673-1702.

13. Kanodia, Chandra; Haresh Sapra, and Raghu Venugopalan. 2004. Should Intangibles Be Measured: What Are the Economic Trade-Offs? Journal of Accounting Research. Vol. 42, No. 1: 89-120.

14. Kohlbeck, Mark and Terry D. Warfield. 2007. Unrecorded Intangible Assets: Abnormal Earnings and Valuation. Accounting Horizons. Vol. 21, No. 1: 23-41.

15. Kumar, T. Krishna. 2005. Disclosure Norms for Intangible Assets: Suggestions for Improving the Valuation of Intangibles. IIMB Management Review. March: 71-78.

16. Laing, Jonathan. 1997. Dangerous Games. Barron's Online. June.

17. Laux, Judith A. 2007. Accounting Issues: An Essay Series Part I-Introduction to Accounting Theory and Cash. Journal of College Teaching \& Learning, Vol. 4, No. 1: 61-65.

18. 2007. Accounting Issues: An Essay Series Part II-Accounts Receivable. Journal of College Teaching \& Learning, Vol. 4, No. 4: 1-6.

19. 2007. Accounting Issues: An Essay Series Part III—Inventory. Journal of College Teaching \& Learning, Vol. 4, No. 8: 1-6.

20. 2007. Accounting Issues: An Essay Series Part IV—Property, Plant, \& Equipment. Journal of College Teaching \& Learning, Vol. 4, No. 11, forthcoming.

21. Lev, Baruch. 2001. Intangibles: Management, Measuring and Recording. Washington, D.C. Brookings Institution Press. 
22. Lev, Baruch and Paul Zarowin. 1999. The Boundaries of Financial Reporting and How to Extend Them. Journal of Accounting Research. Vol. 37, No. 2: 353-385.

23. Liu, Qiao. 2006. How Good Is Good News? Technology Depth, Book-to-Market Ratio, and Innovative Events. Journal of Accounting, Auditing \& Finance. Vol. 21, Issue 3: 293-321.

24. Loudder, Martha L. and Bruce K. Behn. 1995. Alternative Income Determination Rules and Earnings Usefulness: The Case of R\&D Costs. Contemporary Accounting Research. Vol. 12, No. 1: 185-205.

25. Mueller, Jennifer M. 2004. Amortization of Certain Intangible Assets. Journal of Accountancy. December: 74-78.

26. Rao, Rajiv. 1997. Garbage In, Garbage Out. Fortune. May 25.

27. Spiceland, J. David; James F. Sepe; Lawrence A. Tomassini. 2007. Intermediate Accounting, $4^{\text {th }}$ ed. McGraw-Hill.

28. Stanwick, Sarah and Peter Stanwick. Sunbeam Corporation: 'Chainsaw Al' and the Quest for a Turnaround. www.auburn.edu/ stanwsd/sunbeam.html.

29. WorldCom Trial-Accountancy Age. www.accountancyage.com/accountancyage/specials/2039195/ worldcom-trial.

30. Wyatt, Anne. 2005. Accounting Recognition of Intangible Assets: Theory and Evidence on Economic Determinants. The Accounting Review. Vol. 80, No. 3: 967-1003.

\section{NOTES}


NOTES 